\title{
Resignations, the (Quasi) Plural Executive, and a Critical Assessment of the Unitary Executive Theory
}

Ronald J. Krotoszynski Jr.

University of Alabama - School of Law, rkrotoszynski@law.ua.edu

Follow this and additional works at: https://scholarship.law.ua.edu/fac_working_papers

\section{Recommended Citation}

Ronald J. Krotoszynski Jr., Resignations, the (Quasi) Plural Executive, and a Critical Assessment of the Unitary Executive Theory, (2013).

Available at: https://scholarship.law.ua.edu/fac_working_papers/571

This Working Paper is brought to you for free and open access by the Faculty Scholarship at Alabama Law Scholarly Commons. It has been accepted for inclusion in Working Papers by an authorized administrator of Alabama Law Scholarly Commons. 


\section{THE UNIVERSITY OF ALABAMA SCHOOL OF LAW}

"Resignations, the (Quasi) Plural Executive, and a Critical Assessment of the Unitary Executive Theory," in SPEECH AND SILENCE IN AMERICAN LAW

Ronald J. Krotoszynski, Jr.

Cambridge University Press 2010, at pp. 83-105 (Austin Sarat, ed.)

This paper can be downloaded without charge from the Social Science Research Network Electronic Paper Collection: http://ssrn.com/abstract=2232139 


\title{
Comment on Chapter 2: Resignations, the (Quasi) Plural Executive, and a Critical Assessment of the Unitary Executive Theory
}

\author{
Ronald J. Krotoszynski, Jr.
}

Professor Seidman has thoughtfully and comprehensively surveyed the moral, political, and legal implications of an executive branch officer's resignation in response to a presidential directive with which an executivebranch officer disagrees. ${ }^{\mathrm{I}}$ Moreover, his taxonomy of eight options - starting with the weakest response of remaining in office and simply acceding to the policy, through intermediate options and concluding with the strongest possible response of noisily and publicly resigning - represents an almost complete menu of options open to an executive-branch officer who disagrees with her boss, the President, about a policy matter. ${ }^{2}$ Professor Seidman's taxonomy, however, does not include an additional, ninth option: remaining in office, but refusing to implement the President's policy. ${ }^{3}$

One's immediate reaction to this proposed addition might be to dismiss it out of hand; after all, if a presidential appointee serves at the will of the President, how could a cabinet secretary refuse to implement a clear presidential order? The most direct answer: an appointee categorically opposed to a policy could force the President to exercise his power of removal by firing the official. In other words, Secretary of State Colin Powell could have considered taking a page from Nancy Reagan's playbook and "just $\mathrm{sa}[\mathrm{id}] \mathrm{no"}$ " when asked to give his Iraq war presentation at the United Nations. Strictly speaking, President George W. Bush could not force

\footnotetext{
'Louis Michael Seidman, "Powell's Choice: The Law and Morality of Speech, Silence, and Resignation by High Government Officials," supra, at $49-\$ 3$ (hereinafter Seidman, supra note I). Id. at so-r.

Id ; but cf. id. at 63 (noting that two aides to President Richard M. Nixon, John Ehrlichman and H. R. Haldeman, routinely ignored particularly outrageous orders from President Nixon).
} 
Secretary Powell to give the speech, nor could President Bush force Powell to resign (whether loudly or quietly).

Would forcing President Bush to fire Powell constitute a distinction without a difference? I think not: the decision to fire a high-ranking cabinet official requires that the White House disclose the dispute to the national media and citizenry; it is perhaps the "noisiest" option ${ }^{4}$ for an incumbent government official who disagrees with the policies of the President. Moreover, nothing in the Constitution or in our constitutional tradition requires that a cabinet secretary resign rather than force the President to exercise his removal power. General Douglas C. MacArthur both declined to follow President Truman's directives and also refused to resign; he forced President Truman to fre him.

Similarly, J. Edgar Hoover, the long-serving director of the Federal Bureau of Investigation, routinely refused to accede to presidential requests regarding FBI operations and investigations. ${ }^{6}$ In theory, any President from Roosevelt to Nixon could have fired Hoover, for good cause, for refusing to comply with a presidential directive; none did. As Professors Kelly, Harbison, and Belz have noted, notwithstanding Hoover's blatant acts of insubordination, "president after president accepted Hoover, not only because they feared his political power but also because they benefitted from the FBI's covert intelligence operations." Thus, unlike MacArthur, Hoover managed to have his cake and eat it too. ${ }^{8}$ One could object, of

4 Seidman, supra note I, at 5o, 53-5.

s Robert J. Donovan, Tumultuous Years: The Presidency of Harry S. Truman, 1949-1953 (W. W. Norton \& Co., 1982), 354-55 (discussing Truman's sacking of Gen. Douglas MacArthur, including President Truman's discussion of the matter with Chief Justice Vinson prior to implementing the decision); and Christopher S. Yoo, Steven G. Calabresi, and Anthony J. Colangelo, "The Unitary Executive in the Modern Era, 1945-2004," Iowa Law Review 90 (2005): 601, 610-2 (discussing President Truman's decision to remove Gen. MacArthur and its aftermath); see also David McCullough, "Truman Fires MacArthur," Military History Quarterly (Autumn 1992): 8.

${ }^{6}$ Alfred H. Kelly, Winfred A. Harbison, and Herman Belz, The American Constitution: Its Origins and Development, 6 th ed. (W. W. Norton \& Co., 1983), 684 ("Led by the shrewd bureaucratic tactician and empire builder J. Edgar Hoover, the bureau became a power unto itself which had the overwhelming support of public opinion.").

7 Id. at $684-5$. Kelly, Harbison, and Belz suggest that the inability of successive presidents to reign in Hoover and the FBI was "symptomatic of the executive's inability to manage his political environment." Id. at 684 .

8 In the early 19705 , President Richard M. Nixon attempted to preempt the FBI by creating a new intelligence service directly under the control of the White House, to be led by presidential aide Tom Huston. Id. at 69r. J. Edgar Hoover, upon learning of the new intelligence program, denounced it publicly as "illegal and unacceptable." Id. at 692. Following Hoover's public denunciation of the Huston program, President Nixon simply abandoned it. Id. 
course, that Director Hoover's deep file cabinet created an effective and insurmountable check on the power of the President to fire him; under this view, Hoover's case is sui generis and does not generally recur.

A more recent example of a cabinet-level secretary refusing to resign, but also refusing to comply with a presidential directive, exists: Attorney General John Ashcroft refused to accede to requests from the White House to approve the use of domestic spying programs. The White House sought a certification from the Department of Justice that ongoing domestic spying programs, involving warrantless wiretaps, were lawful. ${ }^{9}$ The department refused to comply with this request; Acting Attorney General James B. Comey, serving while Attorney General Ashcroft sought surgical treatment for pancreatitis, informed the White House that the Department of Justice would not provide the requested certification. ${ }^{\text {. }}$

In a now famous incident, on March I0, 2004, then-White House Counsel Alberto R. Gonzales and Chief of Staff Andrew H. Card, Jr., hoping that Ashcroft himself might overrule Comey's decision, visited Attomey General Ashcroft's hospital room while he was recovering from gallbladder surgery, and asked Ashcroft to sign the certification personally, thereby permitting the program to be lawfully renewed. ${ }^{\text {II }}$ According to contemporaneous notes taken by FBI director Robert S. Mueller, III, Attorney General Ashcroft refused to sign the order and instead directed Gonzalez and Card to take the matter up with the acting attorney general. ${ }^{12}$ In fact, Comey was so concerned about the White House attempting to take advantage of Ashcroft that he had previously requested that Mueller bar anyone other than Ashcroft's wife from his hospital room. ${ }^{\text {I3 }}$

The White House continued the program without obtaining the necessary certification, which the Department of Justice steadfastly refused to provide after Ashcroft's return. In order to prevent mass resignations at the Department of Justice and the FBI, including the resignations of both Director Mueller and Deputy Attorney General Comey, the White

\footnotetext{
"David Johnston \& Scott Shane, "Notes Detail Pressure on Ashcroft Over Spying," New York Times, Aug. 17, 2007, Ar4; Dan Eggen \& Paul Kane, "Gonzales, Senators Spar on Credibility; Account of Meeting in '04 Is Challenged," Washington Post, July 25, 2007, AI.

to Johnston \& Shane, supra note 9, at Ar4.

II Jeffrey Rosen, "Conscience of a Conservative," New York Times, Sept. 9, 2007, \$ 6, 40.

${ }^{12}$ Dan Eggen, "FBI Director's Notes Contradict Gonzales's Version of Ashcroft Visit," Washington

Post, Aug. 17, 2007, AL. 
House agreed to make changes to the program. ${ }^{14}$ For present purposes, the key point is that Attorney General Ashcroft refised to do the bidding of the White House, nor did he feel compelled to resign over the incident. President Bush would have been free to fire Ashcroft for his insubordination, but doing so would have revealed in a very public way the rift within the Bush administration regarding the legality of its domestic spying program - to say nothing of potentially disclosing the existence of the program itself. ${ }^{\text {IS }}$

Although this incident is perhaps the most widely known, it is not unique to Ashcroft's tenure as attorney general. When the assistant attorney general position became vacant at the Office of Legal Counsel (OLC), Ashcroft sent the White House a list of five names to consider for the appointment; John Yoo's name, however, was not on Ashcroft's list. ${ }^{16}$ White House Chief of Staff Card called Ashcroft a few hours after receiving the list to inform the attorney general that the White House would not consider any of his proposed nominees. The use of coercive interrogation techniques, also known as "torture," stood at the crux of this dispute; Vice-President Cheney and his chief legal advisor, David S. Addington, wanted Yoo at OLC in order to ensure that the Department of Justice would routinely authorize practices that constitute torture. Attorney General Ashcroft did not repose confidence in Yoo and was unwilling to work with him in the OLC post.

Attorney General Ashcroft did not resign or threaten to resign, but simply refused to accept Yoo in the OLC post; "[t]hrough a White House liaison, Ashcroft told Bush that Yoo was unacceptable." In In turn, "Ashcroft's refusal created a tense standoff and was the only time in the attorney general's tenure that [President] Bush was called upon to resolve a personnel dispute. ${ }^{\prime 8}$ Had Ashcroft resigned, he would have been unable to block Yoo's appointment to the critically important OLC post. By choosing not to

14 The nature and scope of these changes have never been reported; however, the modifications were sufficient to prevent the mass resignations from the Department of Justice and the FBI.

15 See, for example, Peter L. Strauss, "The Place of Agencies in Covernment: Separation of Powers and the Fourth Branch," Columbia Law Review 84 (1984): 573, 590 ("An administrator with a public constituency and mandate, such as William Ruckelshaus, cannot be discharged - and understands that he cannot be discharged - without substantial political cost.").

${ }_{16}$ Carrie Johnson, "Administration Wanted Loyalist as Justice Dept. Legal Adviser; Top Officials Sought to Defend Interrogation Practices," Washington Post, July 17, 2008, A4.

${ }^{17}$ Id. ${ }^{\mathrm{I} 8}$ Id. 
cooperate - essentially, holding both his ground and his office - Attorney General Ashcroft succeeded in blocking the appointment of someone at OLC who lacked the requisite independence from the White House to undertake the duties of that office properly.

The portrait that emerges of Attorney General Ashcroft is complex: a high-level presidential appointee who routinely refuses to take orders from the president presents a very different model from the traditional understanding of presidential control over cabinet departments. ${ }^{\text {I9 }}$ Moreover, his behavior is completely inconsistent with the broadest theories of presidential authority, lately grouped under the "unitary executive" theory of the presidency. ${ }^{20}$ Ashcroft essentially took the position that he had an independent ability to execute the duties of his office unless and until the President removed him from it; the power to remove him from office did not encompass a parallel power to command his behavior while holding the office. In sum, Ashcroft's behavior points the way toward a third model: refusing to implement a misguided policy, while also refusing to resign from office. ${ }^{2 .}$

In the balance of this essay, I will explore the plausibility of taking a "just say no" approach to misguided presidential directives. Is such behavior consistent with the Constitution itself? Or, alternatively, does Article II require that an executive officer holding office at the president's pleasure either accept and implement presidential commands or resign? At a more practical level of analysis, is it plausible to imagine a cabinet-level

19 See Seidman, supra note 1, at 75-6 (noting that although contemporary statutory and constitutional law does not provide firm limits on resignations from appointed executive-branch office, "a well-established line of authority recognizes the power of Congress to limit the President's removal authority with respect to certain executive branch officials," presumably including the Attorney General).

${ }^{20}$ For a thorough legal, political, and jurisprudential history of the "unitary executive" theory, see Mark T'ushnet, "A Political Perspective on the Theory of the Unitary Executive," SSRN Paper No. 1397746 , http: //ssm.com/abstract $=1397746$.

${ }^{21}$ Professor Seidman notes this possibility in passing when recounting the attitude of midnineteenth-century federal judges toward the enforcement of fugitive slave laws that ostensibly required the return of runaway human slaves to their owners. Seidman, supra note 1, at 57-58. Discussing Lysander Spooner's view that the fugitive slave laws were akin to a weapon to be used against an "innocent and helpless victim," Spooner advocated accepting federal judicial office but instead of simply enforcing fugitive slave laws, using the position to combat their enforcement. Using the weapon analogy, Spooner argued that a federal judge should "keep the weapon and use it, in violation of the condition, to defend rather than attack the victims." Id. at 58. This essentially constitutes an approach of intentional defiance: the judge should both refuse to resign and also refuse to enforce laws requiring the repatriation of human beings to chattel slavery status. 
secretary refusing to comply with a presidential directive? And, what bearing does the existence of a phalanx of "independent" agencies within the executive branch have on the proper resolution of these questions? In other words, if we accept that President Obama cannot directly command Federal Reserve Board Chairman Ben Bernanke, should we reflexively assume an ability to command Secretary of State Hillary Rodham Clinton? ${ }^{22}$

If the text of Article II does not mandate a binary choice of acquiescence or resignation, the possibility of simply refusing a misguided presidential command might be more plausible than one initially might suppose. If one also considers the modem practice of creating polycentric executivebranch entities with only attenuated and indirect forms of presidential control, the theoretical objections to a "faithless steward" become even less pressing. Rather than a "unitary executive," in practice the United States has a kind of plural executive; within this structure, the holder of congressionally delegated responsibilities should be free to reject presidential demands; the power to fire does not imply, or at least should not imply, a corresponding power to control an executive officer like a ventriloquist's dummy. ${ }^{23}$

22 Compare A. Michael Froomkin, "The Imperial President's New Vestments," Northwestern University Law Review 88 (1994): $1345,1372-4$ (arguing that Congress may constitutionally vest the execution of laws in specific executive-branch personnel, but noting that "a reasonable reading of the Take Care Clause may require that the President retain the power to dismiss for 'cause' over all persons in the executive branch and further recognizes that precisely what constitutes 'cause' in the constitutional sense remains incompletely defined") (emphasis in the original); with Strauss, supra note 15 , at 602 ("The responsibility of government was to be focally his [the President's]; but day-to-day administration and decision, of necessity, was to be entrusted to the hands of others.").

${ }^{23}$ See Morrison $v_{*}$ Olson, 487 U.S. 654, 697-9, 705-9 (1988); A. Michael Froomkin, Note, "In Defense of Administrative Agency Autonomy," Yale Law Journal 96 (1987): 787, 812-14 (arguing that the power to remove an executive-branch officer for good cause should not, and does not, imply the ability to control her actions directly); Lawrence Lessig, "Readings By Our Unitary Executive," Cardozo Law Review is (1993): 175, 176-7, 182-93 (discussing practices in the early years of the federal government in which Congress provided only attenuated forms of presidential control over key executive-branch agencies, such as the Department of Justice, and suggesting that these practices of providing limited presidential control seriously undermine claims to an unfettered power of the president personally to direct all work within the executive branch); Morton Rosenberg, "Congress's Prerogative Over Agencies and Agency Decisionmakers: The Rise and Demise of the Reagan Administration's Theory of the Unitary Executive," George Washington Law Review 57 (1989): 627, 652-5 (discussing limited direct presidential control over significant activities within the Department of the Treasury in the early years of the Republic). 


\section{The Constitutional Text and the Limited Case for the Unitary Executive}

The framers of the Constitution of 1787 created a unique national office in the presidency. Unlike the legislative and judicial branches, which would be headed by collegial institutions, Article II squarely vests the executive power of the United States in the president: "The executive power shall be vested in a President of the United States of America." ${ }^{24}$

Some judges and legal academics have argued that, in combination with the faithful execution clause, ${ }^{25}$ the vesting clause of Article II requires that the president enjoy plenary control over the activities of the executive branch of the federal government. ${ }^{26}$ As Justice Scalia has explained it, "[i]t is not for us to determine, and we have never presumed to determine, how much of the purely executive powers of government must be within the full control of the President. The Constitution prescribes that they all are."27

Certainly the vesting of executive duties outside of entities located within the executive branch, or placing the responsibility for the execution of federal laws entirely in the hands of personnel not appointed by or accountable to the president, would raise serious constitutional

24 U.S. Constitution, Article II, \& I.

${ }^{25}$ U.S. Const. art. II, $\$ 3$ (providing that the President "shall take Care that the Laws be faithfully" executed").

${ }^{26}$ Steven G. Calabresi \& Kevin H. Rhodes, "The Structural Constitution: Unitary Executive, Plural Judiciary," Harvard Law Review IOS (I992): II53, II65-7, I207-08; Saikrishna Prakash, Note, "Hail to the Chjef Administrator: The Framers and the President's Administrative Powers," Yale Law Joumal ro2 (1993): 99I, 992; Geoffrey P. Miller, "Independent Agencies," Supreme Cout Review (I986): 4I, 44-5, 96-7; see also Susan M. Davies, Note, "Congressional Encroachment on Executive Branch Communications," University of Chicago Law Review 57 (1990): 1297, 1302 ("They [the Framers] created a unitary executive, popularly elected and politically accountable: a single person in whom all executive power would reside."). It bears noting, of course, that the Framers did not provide for popular election of the President, see U.S. Const. art. II, $\mathrm{S} \mathrm{I}_{\mathrm{cl}} \mathrm{cl} 2$ ("Each State shall appoint, in such Manner as the Legislature thereof may direct, a Number of Electors, equal to the whole number of Senators and Representatives to which the State may be entitled in Congress... ."), and the equal voting rights of the states in the U.S. Senate make the Electoral College's composition deeply undemocratic, that is, states with very small populations, such Wyoming and Alaska, enjoy grossly disproportionate voting strength in the Electoral College. Thus, the House of Representatives has more democratic legitimacy than the President, if democratic legitimacy requires respect for the principle of equal voting power among citizens. See Reynolds v. Sims, 377 U.S. 533 (1964); and Baker y. Carr, 369 U.S. 186 (1962).

27. Morrison, 487 U.S. at 709 (Scalia, J., dissenting) [emphasis in the original]. 
concerns. ${ }^{28}$ Thus, Congress could not constitutionally vest the conduct of foreign relations in the federal courts, or appoint one of its own members to conduct the foreign policy of the United States. ${ }^{29}$ The question of another branch attempting to encroach on core executive functions and to aggrandize itself by usurping these functions raises an easier question, however, than an attempt to limit the direct personal control of the president over the execution of a law. ${ }^{30}$

Even if Congress cannot condition the discharge of an executive-branch officer on the consent of one or both houses, the Supreme Court has sustained limitations on the president's power to remove executive-branch officials, including statutes that limit the power to fire an executive officer with substantial policymaking responsibility to "good cause" discharge..$^{3 \mathrm{I}}$ If Congress, when creating independent executive agencies, may limit the president's power of removal to good cause - with "good cause" ultimately to be decided by the federal courts rather than the president - the notion

${ }^{28}$ For example, if Congress attempted to vest execution of a federal law with state governors rather than federal officers, the president would have no effective ability to ensure "faithful execution" of the law in question, nor would that aspect of the executive power be vested in the president. Compare M'Culloch v. Maryland, 17 U.S. 316 (1819) (holding that Maryland could not directly tax the Bank of the United States because a part cannot control an agency of the whole; by parity of reasoning, the control of a federal responsibility with a part (a state governor) also impermissibly attenuates national control over federal responsibilities); with New York $\nu$. United States, 505 U.S. 144 (1992) (invalidating on federalism grounds a federal law that "commandeered" state legislatures to implement federal policies).

29 See Buckleyv. Valeo, 424 U.S. 1, 121-3, 126-9, 137-42 (1976) (invalidating on separation of powers grounds the appointment of executive-branch officers by Congress); and Bowsher v. Synar, $47^{8}$ U. 714,726 (1986) ("Congress cannot reserve for itself the power of removal of an officer charged with the execution of the laws except by impeachment."). One should note that Article II expressly provides that the president "shall receive Ambassadors and other public Ministers," plainly vesting the president with responsibility for conducting diplomatic relations with other nations. See U.S. Const. art. II, S 3. The President's authority over foreign affairs is further confirmed by the power to make treaties, with the advice and consent of two-thirds of the Senate, and the power to nominate and appoint, with the advice and consent of the Senate, Ambassadors. Id. at art. II, $\int 2$, cl. 2.

${ }^{30}$ Compare Myers v. United States, 272 U.S. $52,116-7,163-4$ (1926) ("Our conclusion on the merits, sustained by the arguments before stated, is that Article II grants to the President the executive power of the Government, i.e., the general administrative control of those executing the laws, including the power of appointment and removal of executive officers-a conclusion confirmed by his obligation to take care that the laws be faithfully executed... .") with Humphrey's Executor v. United States, 295 U.S. 602, 629-30 (1935) ("We think it plain under the Constitution that illimitable power of removal is not possessed by the President in respect of officers of the character of those just named.").

${ }^{3 s}$ Mistretta y. United States, 488 U.S. 36I, 4I0-II (1989); Morrison y. Olson, 487 U.S. 654, 69I-3 (1988); Humphrey's Executor v. United States, 295 U.S. 602, 629-3I (1935). 
that the president must be able to repose absolute confidence in all of his subordinates rings false; in fact, the president might well have to tolerate subordinates in whom he utterly lacks confidence, if the "good cause" standard for discharge cannot be met. Moreover, although there is some debate in the literature on this point, a mere disagreement about the best policy options would not likely constitute "good cause" for discharge. ${ }^{32}$

The Supreme Court might limit the duties that could be vested with an independent agency, in order to ensure that persons more directly accountable to the president execute "core" executive functions. Yet, one would be hard pressed to think of a more quintessentially executive duty than the prosecution of crimes; nevertheless, the Supreme Court approved the creation of an Office of the Independent Counsel to investigate highranking executive-branch personnel, with the appointment made by a panel of federal judges, and with the president's power to remove the appointee limited to "good cause" considerations, such as disability, malfeasance, or other serious misconduct. ${ }^{33}$ Chief Justice Rehnquist, writing for the 8-to-I Morrison majority, found that an independent counsel constituted an "inferior officer" for purposes of the appointments clause ${ }^{34}$ and that the "good cause" removal provisions provided a sufficient measure of presidential control over the office. ${ }^{35}$

${ }^{32}$ Humphrey's Executor seems to stand for this proposition. President Franklin D. Roosevelt removed Humphrey from the Federal Trade Commission not for failing to attend meetings or taking bribes but rather because Humphrey, an appointee of President Herbert Hoover, did not share Roosevelt's policy preferences for how the agency should approach exercising its institutional jurisdiction. As President Roosevelt explained in a letter of August 31, I933, to Commissioner Humphrey, "You will, I know, realize that I do not feel that your mind and my mind go along together on either the policies or the administering of the Federal Trade Commission, and, frankly, I think it best for the people of this country that 1 should have a full confidence." Humphrey's Executor, 295 U.S. at 619. Humphrey ignored President's Roosevelt's request that he resign and on October 7,1933 . President Roosevelt attempted to remove Humphrey from the Federal Trade Commission. Id.

${ }^{33}$ Morrison v. Olson, 487 U.S. 654, 689-93, 694-7 (1988). Moreover, the statute at issue, the independent counsel provisions of the Ethics in Government Act, 28 U.S.C. $8 S 591-9$ ( 1982 ed.), actually vested the power to remove an independent counsel with the attomey general rather than the president. See id. at $\int 596(\mathrm{a})$; see also Morrison, 487 U.S. at $69 \mathrm{I}-3$ (sustaining Congress's decision to vest removal of an independent counsel with the attomey general, only for the good cause reasons set forth in section 596 (a), and subject to review in a federal district court). Thus, in a technical sense, the president enjoyed only an indirect power to remove an independent counsel; instead, the attorney general - subject to judicial review - possessed this authority.

${ }^{34}$ Id. at $670-7 . \quad 35$ Id. at $69 \mathrm{I}-3$. 
Taking Morrison as a baseline, it becomes entirely plausible to posit that the power to fire an executive officer does not necessarily imply the power to command or control a duly appointed executive-branch official holding office. Moreover, even if the separation of powers would not permit Congress to grant formal job protection to an officer vested with broad authority over a core executive function, such as the secretary of state or the attorney general, existing blackletter law seems to support the proposition that a delegation to a particular executive-branch official gives that official, and not the president, the power to exercise the duties of the office in question.

In fact, the text of the Constitution seems to support this analysis. The faithful execution clause, intentionally written in the passive voice, charges the president with "tak[ing] Care that the Laws be faithfully executed," 36 not with "faithfully executing" the laws himself. Thus, the framers" language bespeaks a duty of presidential oversight over subordinate officers within the executive branch, rather than a direct power of presidential action or control. Certainly the responsibility for ensuring faithful execution of the laws by others implies an ability to remove impediments to this objective, presumably including the power to discharge inept or corrupt subordinates within the executive branch. The point, however, remains that the power to remove a subordinate officer within the executive branch is simply not the same thing as the power to control or compel a subordinate officer to act or to refrain from acting.

If this view is correct, even if the president has the power to fire a person holding an executive office, he would not necessarily enjoy the power to command them to undertake a particular task in a specific way or resign. In other words, if a person were willing to risk discharge, there is nothing constitutionally problematic with a high-ranking government official telling the president "no" with respect to a major policy issue about which the president and the presidential appointee disagree. Faced with such a refusal, the president's options would include accepting the insubordination or sacking the appointee. And, the recent history of Attorney General Ashcroft would suggest that high-level presidential appointees sometimes do "just say no" when asked to approve policies or subordinates.

${ }^{36}$ U.S. Const. art. II, , $\$ 3$. 
Notwithstanding the vesting and faithful execution clauses, some textual warrant exists in the Constitution itself for the view that executive officers are not necessarily mere lapdogs of the president. Article II, section 2, clause I provides that " $t]$ he President... may require the Opinion, in writing, of the principal Officer in each of the executive Departments, upon any Subject relating to the Duties of their respective Offices." ${ }^{37}$ If Article II gives the president virtually unfettered authority over presidential appointees, why would the framers have included a specific clause that expressly grants the president the power to require appointees to provide written opinions regarding matters falling within "the duties of their respective offices"? Note also that this power is facially limited to the "principal officer" within an executive department; it does not encompass inferior officers within an executive department. If the framers understood the president to have unlimited authority over executive officers, why would they have included such a clause in Article II?

As one astute legal scholar has argued, "[a] reasonable interpretation of the Opinions Clause is that it exists because it was not assumed, or at the very least not obvious, that the President had absolute power over heads of departments. ${ }^{38}$ Thus, the presence of the opinions clause suggests that the president's authority over subordinates would be somewhat circumscribed; even if the president had the power to fire an appointee, he did not necessarily have the power to otherwise control or compel an appointee to do a particular task, even a task as innocuous as offering an opinion, in writing, about the operations of the department. ${ }^{39}$

\section{Il. The Unitary Executive Theory's Implications for "Just Saying No"}

I would be remiss not to note that the some public law scholars, advocating a "unitary executive theory," have essentially argued that the president must be able to personally direct the work of subordinate executive-branch

${ }^{37}$ Id. at art. II, $\int_{2}, \mathrm{cl} .2 .{ }^{38}$ Rosenberg, supra note 23 , at 689 .

39 Froomkin, "In Deferise," supra note 23 , at $800-1$ (arguing that the opinions clause refutes the inference that the president should enjoy plenary power over all executive-branch officers and asking "ii)f the President has so much control over the executive that he can fire at will, why put the powver to request written opinions in the Constitution?"); Rosenberg, supra note 23, at 689-90 ("A broad reading of the Take Care Clause would have the effect of reducing the Opinions Clause-which appears among the grant of major presidential powers in section two-to surplusage."). 
officers. For example, Professor Steven G. Calabresi has argued that " $t \mathrm{t}$ ]he President could not possibly be said to have all of the executive power in order to be able to take care that the laws be faithfully executed if he could not tell his subordinates what to do." ${ }^{40}$ Adherents of this theory of executive power believe that "the President alone possesses all of the executive power and that he therefore can direct, control, and supervise inferior officers or agencies who seek to exercise discretionary executive power." ${ }^{\text {"I }}$ The implications of this construction of presidential authority are quite significant; as Calabresi notes: "It renders unconstitutional independent agencies and counsels to the extent that they exercise discretionary executive power." ${ }^{22}$

In a similar vein, Professor Saikrishna Prakash has argued that "[w] henever an official is granted statutory discretion, the Constitution endows the President with the authority to control that discretion." 43 Thus, "even if a statute grants discretion to the secretary of state and explicitly prohibits presidential intervention in the decision-making process, the president retains the constitutional authority to substitute his own judgment for the secretary's determination." 44

Indeed, Prakash is particularly emphatic in his view that "Congress, however, has gone beyond its established role and has vitiated several decisions of the Constitutional Convention." "4s In particular, Congress has (I) "resuscitated the plural executive in the form of independent agencies," (2) "splintered responsibility for execution of federal law among numerous agencies," and (3) "established independent administrative officers" ${ }^{\text {"6 }}$ - all decisions that Professor Prakash views as patently unconstitutional. In his view, these developments have rendered Article II's vesting and faithful execution clauses mere "nullities."47 Thus, the unitary executive theory, at least in its strongest iteration, would result in the nullification of all limits on presidential control of independent executive-branch agencies that exercise

40. Calabresi \& Rhodes, supra note 26 , at 1207 . "Id. at 1165 .

(emphasis in the original). To be clear, the advocates of the unitary executive do not presterm a mandatory ministerial argue that the president may order a subordinate to refuse perforidential control over task. See id. at 1166 n. 53 ("The unitary executive debate con (emphasis in the original)). discretionary exercises of execu

43 Prakash, supra note 26, at 992 .

44 Id.; see also Calabresi \& Rhodes, supra note 26 , at direct presidential usurpation of duties unitary executive theory and positing the legality of dive Federal Trade Commission, or by delegated to another executive-branch entic

parity of logic, the Federal 26 , at 1016. ${ }^{4} 6$ Id. 47 Id. at 1017. 
sski, Jr.

$t$ "[t]he ower in e could ecutive z power icers or a implicant; as ies and wer." 42 zd that ititution stion." 43 ate and ig prochis own

ongress, several iress has encies," imerous ;"46-all 1. In his faithful leory, at imits on exercise

tive do not ministerial ontrol over 1)).

sm" of the $\mathrm{n}$ of duties ision, or by

policy-making authority, such as the Federal Communications Commission or the Federal Reserve Bank of the United States.

The vesting and faithful execution clauses serve as the linchpin of unitary executive theories. The argument posits that unless the president can personally direct the decisions of executive-branch officers, he may not plausibly be said to enjoy the full executive power nor may he ensure that subordinates faithfully execute federal laws. ${ }^{48}$ Professor Prakash argues that "[t]he Framers did not labor over the executive's duties under the Take Care Clause merely to create a glorified busybody who could only look over the shoulders of others to determine if they were faithfully executing federal law." "Instead, "[t]he Framers wanted the President to execute the law; in the Constitution, no other officer is so charged."

The implications of the unitary executive theory for post-New Deal administrative agencies would be quite remarkable:

If the Framers wanted the President to execute federal law, may Congress (consistent with original intent) create administrative agencies that execute federal law without presidential supervision and control? The answer is no. The choice of who is constitutionally responsible for executing federal law was made in Philadelphia. ${ }^{\text {sI }}$

Thus, under the strongest iteration of the unitary executive theory, the president must have the power to appoint and directly control all persons working within the executive branch of the federal government. Consistent with this approach, it would be quite impossible for a cabinet secretary to refuse a presidential order - under this theory of presidential power, Secretary Powell had a constitutional duty to do whatever President Bush instructed him to do. ${ }^{52}$

${ }^{48}$ Sec id. at Ioo3; see also Morrison v. Olson, 487 U.S. 654, 705 (1988) (Scalia, J., dissenting) (arguing that the vesting clause "does not mean some of the executive power, but all of the executive power"); Calabresi \& Rhodes, supra note 26, at In77-9 (discussing the mandatory nature of the Article II vesting clause and that the vested executive power belongs to the president alone).

${ }^{49}$ Prakash, supra note 26, at 1003. 5o Id. SI Id.

52 Calabresi \& Rhodes, supra note 26, at II65; Prakash, supra note 26, at I003; and Miller, supra note 26, at 44, 97 (arguing that the President may issue binding instructions to members of independent federal agencies and, if the agency ignores those orders, may fire agency members for insubordinationj. As Professor Miller states the matter, "[a] though the President cannot personally take the action necessary to implennent a statutory authority vested in particular agencies, the President can make his or her views known to the agency official and can remove the official if the ultimate decision is contrary to the President's instructions." Id. at 97. The distinction turns on whether the president can constitutionally force a subordinate to work his will or whether the president may give instructions to subordinates, but discharge them if they fail to implement his directives. 
There are obvious and powerful objections to the unitary executive on theory of presidential authority. Professor Lawrence Lessig, assuming the relevance of original intent for the sake of argument (but also noting that its relevance is a highly contestable proposition), nevertheless found multiple examples of limited presidential control of executive officers in the early years of the Republic. ${ }^{53}$ Based on this evidence, Lessig posits that "the practice of the executive in the early republic was inconsistent, or at least in tension, with the unitarian's claim that the executive possesses an inherent power to direct and control all inferior officers." ${ }^{44}$

Moreover, at a more practical level, it is clear beyond peradventure that the Supreme Court has not, and probably will not, adopt the unitary executive theory of presidential control of the executive branch; on the contrary, the Court has gone out of its way to sustain limits on direct forms of presidential control of executive-branch officers (even prosecutors). ${ }^{55}$ Moreover, the Justices have not drawn any distinction between discretionary duties and ministerial tasks when examining statutes that vest discretionary powers with executive-branch officers not subject to direct forms of presidential control; existing constitutional law plainly permits Congress to vest executive authority in independent agencies and commissions without transgressing the separation of powers. Thus, one simply cannot square the model of plenary presidential control over the executive branch advocated by proponents of the unitary executive theory with the controlling Supreme Court precedents on point.

Why then has so much ink been spilled in pursuit of the unitary executive theory? Lessig plausibly argues that "[u]nitariness is our focus because we have come to believe that unitariness (as we have come to understand that notion) was essential to the Framers' design." ${ }^{56}$ In other words, because modern constitutional scholars assume a unitary executive as a baseline, we seek out confirmation of that assumption when reading the historical and legal record. As he puts the matter, "We believe the Constitution is unitarian, so we see unitarianism in all things the Framers did. Believing is seeing." 57

From a textual perspective, the unitary executive theory has trouble making sense of the opinions clause, which seems to suggest unstated limits

53 Lessig. supra note 23 , at $182-96.54$ Id. at 196 (emphasis in the original).

55 See supra text and accompanying notes 28 to 39 . 
synski, Jr.

executive Iming the ng that its 1 multiple the early that "the or at least ; an inher-

nture that re unitary sh; on the irect forms ;ecutors). ${ }^{55}$ discretionrest discrect forms of Jongress to ins without square the advocated g Supreme

he unitary 3 our focus ve come to ${ }^{55}$ In other y executive reading the believe the he Framers

has trouble stated limits

on the scope of presidential control of subordinates. Supporters of the unitary executive theory have adopted a simple (and expedient) interpretative move to address the opinions clause problem: they simply read the opinions clause out of the Constitution as a redundancy, given the presence of the vesting and faithful execution clauses..$^{58}$ Professor Prakash takes an even bolder approach, arguing that "the Framers arguably included this provision [the Opinions Clause] to facilitate presidential control of discretion." 59 Under this approach, "[t]he Written Opinions Clause means that the President may ask for the considered opinions of the department heads and implies that the President will make the ultimate decision." ${ }^{\circ 0}$ In either case, advocates of the unitary executive theory believe that "its text does not impose limits on the President's power over the executive department."

The problem with these arguments is that they rest either on reading the opinions clause out of the Constitution or positing a conclusion as an argument. For example, Calabresi objects that " $[\mathrm{t}]$ he President could not possibly be said to have all of the executive power in order to be able to take care that the laws be faithfully executed if he could not tell his subordinates what to do. ${ }^{\text {"62 }}$ But this begs the question of the precise mechanism of presidential control over subordinate executive-branch officers; there is nothing inconsistent with positing an ability to request an opinion and to use the answer provided as a basis for pursuing a "for cause" dismissal of the officer in question. Moreover, the ability to monitor and, if necessary, discharge subordinates in no way nullifies either the vesting clause or the take care clause. There is simply no reason to view more circumscribed presidential control over subordinates as fundamentally inconsistent with the framers' institutional design.

It also bears noting that the opponents of the unitary executive theory do not ignore the vesting and faithful execution clauses. For example, Professor

${ }^{58}$ Prakash, supra note 26, at 1004 (noting that some advocates of the unitary executive theory "contend that the Written Opinions Clause is a mere superfluity and not worth serious discussion or attention."); see also Davies, supra note 26, at 1302 ("The Opinion Clause makes explicit the authority of the President to receive information from his subordinates and to direct their performance of administrative activities, thereby insuring his ability to wield his constitutionally defined powers effectively.").

59 Prakash, supra note 26, at roos; see id, at 1007 ("Instead of detracting from the Chief Administrator theory, the clause, interpreted in its full historical context, may actually advance the theory.").

${ }^{60}$ Prakash, supra note 26, at 1007. 6r Calabresi \& Rhodes, supra note 26, at 1207. ${ }^{62}$ Id. 
Froomkin freely concedes that the President must have the ability to oversee the performance of executive duties; thus, Congress could not remove all presidential oversight of independent administrative agencies, ${ }^{63}$ nor could it delegate federal administrative power to state government officers or private entities. ${ }^{64}$ Thus, Froomkin argues that "[i]n some areas, such as foreign affairs, the President has power to remove at will regardless of what Congress may legislate; in other areas, where the enumerated powers are more closely matched, Congress has the power to require 'cause' for dismissal but perhaps not more."

The real question should not be whether the president enjoys omnipotence over all of his subordinates, but rather whether congressional limits on presidential control over subordinates frustrates democratic accountability over the executive branch. As Froomkin states the matter, "[p]lurality in the executive is suspect when it diminishes democratic accountability." Adoption of a "for cause" standard for discharge enhances, rather than reduces, democratic accountability because "it requires that the President give reasons for a dismissal that can then be examined either by Congress and the people or by a court." ${ }^{67}$ A "for cause" limitation on discharge "imposes political consequences for unwarranted dismissals in sensitive domestic offices" and enhances public accountability by "put[ting] the President on notice that Congress and the people will expect a reasoned explanation for personnel changes (and ensuing policy swerves) in critical offices." ${ }^{68}$

Like Professor Froomkin, Professor Strauss approaches the question of presidential control over executive-branch personnel from a deeply pragmatic, rather than ideological, point of view. For Strauss, a balance of power between Congress and the president requires that the president enjoy some measure of control over subordinates, including the ability to appoint agency heads, that the agency have a relationship with the president that is "consonant with his obligation to see to the faithful execution

${ }^{63}$ A. Michael Froomkin, "Still Naked After All These Words," Northwestern University Law Review 88 (I994): 1420, I432-3.

64 A. Michael Froomkin, "Wrong Turn in Cyberspace: Using ICANN to Route Around the APA and the Constitution," Duke Law Joumal so (2000): 17, I46-50; A. Michael Froomkin, "Reinventing the Government Corporation," University of Illinois Law Review (1995); 543, 574-6, 608-I2.

65 Froomkin, "Still Naked," supra note 63, at I432-3. ${ }^{66}$ Id. at I433. ${ }^{67}$ Id. ${ }^{68}$ Id. at I434. 
of all laws," and "the authority to demand written reports of the agency prior to its action on matters within its competence, with the strong implication that consultation if not obedience will ensue." ${ }^{\text {"S9 }}$ Strauss advocates a "substantial presidential relationship with any agency performing a significant governmental duty exercised pursuant to public law." "[e]ven the most modest notion of what constitutes executive power suggests that the President must retain substantial lines of communication and guidance."7r

Professor Strauss's concerns do not lie so much with the framers' intentions or the Federalist papers, but rather with practical concerns about the wisdom of insulating government policy from any serious form of executivebranch oversight by the president. Congress and the president openly compete for control of federal agencies; if the president could not appoint or remove agency heads; if an agency could refuse to provide the president with information regarding its actions; if an agency could refuse to consider presidential priorities when exercising delegated authority from Congress, the balance of power would shift significantly in favor of Congress calling the shots. "To deny the President that authority would be to deprive him and the public of that responsibility, and effectively to permit the Congress, again, to establish multiple centers of law administration primarily under its control." 72

Thus, Strauss has a powerful normative objection to the unfettered exercise of both legislative and executive power by Congress; this is certainly a concern shared by the framers, but the principal goal is securing sound governance, rather than honoring some hoary and ill-defined original intention of the framers. Presidential oversight of executive agencies, including relatively independent executive agencies, promotes better policymaking and makes government more accountable. The ability to communicate with subordinates and to demand information from subordinates is simply essential to the ability of the president to ensure "faithful execution" of the laws. Thus, even legal scholars who do not generally embrace the broadest iterations of the unitary executive theory would agree that the president must have some measure of control over all executive officers.

\footnotetext{
${ }^{69}$ Strauss, "Place of Agencies," supra note I5, at 640-I; see also Peter L. Strauss, "Overseer or "The Decider'-The President in Administrative Law," George Washington Law Review 75 (2007): 696.

$7^{70}$ Strauss, "Place of Agencies," supra note 15, at 641. ${ }^{71}$ Id. at $642 . \quad 7^{72}$ Id.
} 
To be clear, I do not endorse or support a genuinely "plural" executive in the sense of a federal executive branch in which multiple free agents implement federal laws and make policy free and clear of any significant presidential oversight. Indeed, I do not know of any legal scholar who would seriously support vesting the implementation of federal law wholly outside the control of the White House. ${ }^{73}$ The question is whether Congress may vest policymaking in particular hands and attenuate direct presidential control over the exercise of these duties. Attenuated presidential control over the exercise of delegated authority, in the form of powers of appointment and removal (even if limited to "good cause") adequately vests the president with the executive power of the United States and permits him to ensure "faithful execution" of the laws. If an executive officer is failing to exercise her duties properly, the president may discharge the officer and appoint a more capable replacement - the requirement of giving public reasons for a discharge does not impede or preclude exercise of the president's removal power. $^{74}$

Advocates of the unitary executive theory demand greater direct presidential control over all operations of the executive branch, but they cannot

${ }^{3}$ This could be accomplished in various ways (at least in theory). Congress could enact a federal law, but vest enforcement of the law with state elected officials or state agencies that are entirely unaccountable to the President. But cf. Printz y. United States, 521 U.S. 898 (1997) (holding inconstutional on separation of powers grounds Congress's attempt to "commandeer" local law enforcement officers to enforce the Brady Act's identity check provisions for gun purchases); New York v, United States, 5os U.S. 144 (1992) (holding unconstitutional on separation of powers grounds Congress's attempt to force state legislators either to join interstate compacts created to provide a shared waste disposal site for the long term storage of locally produced low level radioactive waste or, alternatively, to take ownership of the waste directly via a "take title" default rule for states that fail to join an interstate compact). Alternatively, Congress could vest the enforcement of a federal law in corporate or private hands. But cf. Carter v. Carter Coal Co., 298 U.S. $238,310-11$ (1936) (invalidating delegation of power to implement a federal program to private parties outside the government and describing the arrangement as "legislative delegation in its most obnoxious form; for it is not even delegation to an official or an official body, presumptively disinterested, but to private persons whose interests may be and often are adverse to the interests of others in the same business"). Either mechanism would result in federal law being enforced by a person or entity entirely outside the sphere of presidential control and would therefore be inconsistent with the Vesting and Faithful Execution Clauses. Moreover, this result would hold true regardless of whether one subscribes to the unitary executive theory of presidential powers. See, for example, Froomkin, "Reinventing the Government Corporation," supra note 64, at 574-7, 608-12; Froomkin, "Still Naked," supra note 63, at 1431-4.

74. Froomkin, "Still Naked," supra note 63, at $1432-4$ (arguing that the power to remove for cause ensures both presidential control and presidential accountability to the Congress and to the citizenry). 
Jr.

in

snts

ant

uld

side

nay

itial

trol

int-

the

$n$ to

$g$ to

and

blic

resi-

resi-

nnot

əderal

ttirely

slding

' local

lases);

rowers

ited to

, level

lefault

est the

o., 298

am to

gation

body,

idverse

ral law

would

$\mathrm{s}$ result

$\mathrm{f}$ presi-

"supra

$r$ cause

to the

offer compelling arguments to support their demand of complete, unfettered presidential control over subordinates. As Lessig's work demonstrates, the framing generation, including both the first congresses and presidential administrations, did not follow this model in structuring presidential oversight of executive-branch operations. ${ }^{75}$ As Lessig puts it, "[a] picture holds us captive" and "the view that the Framers embraced anything like the unitarianism spouted by the modern unitarians is just plain myth." ${ }^{76}$ Importantly, the Supreme Court itself has been presented with multiple opportunities to embrace the unitary executive theory, but has rejected it, by overwhelming margins, with only Justice Scalia embracing - in dissent and alone - the broadest claims of unfettered executive control.

In sum, although advocates of the unitary executive theory certainly have developed a plausible conception of the proper scope of presidential authority, their vision is not supported by historical practice, contemporary precedent, or even the text of the Constitution itself. It is at best a plausible, but not compelling, model of the appropriate separation of powers. Accordingly, an executive officer should not feel bound to observe the dictates of the president or resign from office; it would be perfectly lawful, and within existing constitutional traditions, for an executive officer, like Attorney General John Ashcroft, to "just say no" without offering to resign from office. ${ }^{77}$ At that point, the ball would be squarely in the president's court: he could accept the refusal and move on or he could remove the subordinate officer (with an expectation that some sort of public explanation would be necessary).

\section{Speech and Silence Revisited: Could Powell Have Simply "Just Said No?"}

Professor Seidman's analysis of the practical limitations on senior executivebranch officials resigning from office, whether quietly or noisily, raises the important question of practical limits on the ability of executive officers to take actions antithetical to the interests of their presidential patron. As Seidman

${ }^{75}$ Lessig, supra note 23 , at $176-7,186-96 . \quad{ }^{76} \mathrm{Id}$. at 176.

77 Seidman, supra note 1 , at $G_{3}$ ("It might even be in the patron's interest for the appointee to ignore the patron's ill-considered orders, as, for example, John Ehrlichman and H. R. Haldeman regularly (but not regularly enought) did when Richard Nixon gave them outlandish and bizarre directives."). 
puts it, "[p]ublic resignations violate norms of personal loyalty, trust, and honesty. ${ }^{" 78}$ Moreover, "[a] public attack on the way out the door for decisions made during one's tenure with information gained because of that tenure is never in the interests of the person attacked." ${ }^{\prime 9}$ A public attack accompanied by a resignation breaches reasonable expectations of "loyalty, trust, and honesty" and "will often be seen by the patron as disloyal and dishonest."

Paradoxically, perhaps, the option of remaining in office but refusing an unreasonable, unlawful, or unconstitutional order risks less public damage to the president, at least in the short term, than a resignation (whether noisy or quiet). Even a quiet resignation is likely to raise public questions about the reasons for the decision to leave, and the timing of a quiet resignation certainly would raise questions that the press would be unlikely to ignore. For example, if during the run-up to the Iraq war, rather than make a factually inaccurate speech to the United Nations Secretary Powell had quietly resigned from office - perhaps citing health or professional reasons the absence of a press conference would not have seriously attenuated the impact of his resignation. A resignation of any sort would have been damaging to President George W. Bush and his administration's goal of obtaining global support for a war against Iraq.

On the other hand, suppose that instead of either giving the United Nations speech or resigning his office, Colin Powell had instead simply refused to give the speech. I have no doubt that President Bush could have fired Secretary Powell for such an act of insubordination, but it would have come at a tremendous cost to the Bush administration; President Bush would have been required to explain his decision to sack his secretary of state, and the truthful explanation ("Secretary Powell does not believe our administration's claims about Iraq and weapons of mass destruction") would have been a public relations disaster. Yet, if a president wishes to impose a policy on a subordinate, he must be willing to use his constitutional power of removal if that subordinate refuses to comply with his wishes. ${ }^{81}$

${ }^{78}$ Seidman, supra note I, at $63 . \quad{ }^{79} \mathrm{Id} .{ }^{80} \mathrm{Id}$.

${ }^{81}$ See Myers v. United States, 272 U.S. 52, I63-4, I76-7 (1926) (holding that the Constitution and consistent historical practice give the president the power to remove subordinate executive officers without seeking the approval of Congress); see also Morrison v. Olson, 487 U.S. 654, 69r-3 (1988) (holding that power to remove an executive officer from office for "good cause" satisfies separation of powers requirements that the executive powers be vested in the president and that the president ensure faithful execution of the laws). 
It would be mistaken, however, to suggest that rampant insubordination reflects an appropriate model for executive-branch officers; if subordinates routinely ignored presidential directives, the president's ability to oversee the operations of the executive branch would cease to exist. Independent of any textualist or originalist arguments, securing sound policy and political accountability for government decisions requires that the buck stop somewhere - diffuse and ill-defined executive power would significantly impede any serious effort at securing accountability or coherency in government policymaking. ${ }^{82}$

Were all executive officers to follow their conscience any and every time they disagreed with the president, chaos would result. Moreover, the removal power will serve as an effective means of securing control only if the president resorts to its use relatively sparingly. The president must rely on subordinates to run the various departments and agencies of the federal government, and he simply could not fire the senior executive political appointees of entire departments. Thus, the threat of removal should serve as an incentive to secure compliance, but its aggressive use would lead to unstaffed positions and a likely paucity of would-be candidates to fill those positions left vacant through presidential removals.

Were "just saying no" to become an accepted and relatively commonplace response to policy disagreements with the president, the United States would truly have a plural executive; as a practical matter, the president would not be able to direct the affairs of the executive branch. Instead, the heads of departments and agencies would enjoy de facto control over policy within their jurisdiction. Over time, "just saying no" might also incent presidents to seek candidates who promise to be loyal, even at the price of competence. It is difficult to see the benefits of adopting such an approach to structuring the relationship between the president and his subordinates.

All of this suggests, rather strongly, that "just saying no" cannot be a commonplace strategy or one used without great circumspection. Only questions of the highest order could possibly justify intentional insubordination by a presidential appointee. And, yet, even if one accepts these caveats and limitations, the question of war in Iraq would seem to hit this mark - as would the question of whether to authorize torture or a domestic spying program. Even if a presidential appointee, like Secretary Powell or

${ }^{82}$ Strauss, "Place of Agencies," supra note I5, at 640-54. 
Attorney General Ashcroft, has a general duty to accept and implement presidential directives, at some point these officers have an independent duty to the law and to the Constitution itself. Although, as Professor Seidman notes, loyalty usually constitutes a virtue, ${ }^{8_{3}}$ the question of where the duty of loyalty ultimately lies remains an open one, at least in some circumstances. Is Secretary Powell's highest loyalty to the President? To the Constitution? Or to the rule of law itself?

It seems to me that circumstances can and will arise in which the question of loyalty will be quite complex; in which the answer of what a "loyal" subordinate should do will be far from clear. Should Secretary Powell have given a speech filled with what he believed to be untruths? Was this admirable? Should we wish for other executive officers to emulate this behavior? Or would the virtuous decision have been simply to refuse to give a speech that contained materials that Powell believed to be false or unreliable? At the end of the day, Powell held the trump card - and it was probably not resignation. Resignation would simply have led to some hard questions being asked by the press, but the speech, or one very like it, would have been delivered by someone else.

The course of action most likely to make a real difference would have been to hold his ground by refusing either to resign or to give a speech Powell deemed untruthful. Just as John Ashcroft neither resigned nor acquiesced in the domestic spying program or the appointment of John Yoo to head OLC, Colin Powell could have stood his ground and dared the President to fire him. It is impossible to know whether this approach might have altered the course of history, but certainly it presented a greater probability of doing so than simply acquiescing in the President's and Vice-President's wish that he serve as the mouthpiece of war with Iraq.

\section{Conclusion}

Neither the Constitution nor our constitutional traditions preclude a presidential appointee from just saying no and refusing to implement a presidential directive that the appointee believes to be unconstitutional, unlawful, or simply misguided. Obviously, taking such a course of action constitutes very strong medicine and meaningful presidential oversight of the executive

${ }^{83}$ Seidman, supra note $I$, at $62-3,71-3,79-80$. 
branch could not exist if appointees routinely adopted a "just say no" modus operandi. Nevertheless, in limited circumstances, holding one's ground might represent a proverbial "third way" that threads the needle between the other options of simply doing as one is told or resigning office in protest.

One also should note that we really do not know how often - or how infrequently - appointees just say no. The public press accounts of Attorney General Ashcroft's refusal to approve a domestic spying program probably represent an unusual circumstance; when a high-level presidential appointee resists a presidential directive, more often than not the general public is not likely to leam about the insubordination. If the president is to maintain control and consistency of the vast federal policymaking apparatus, however, one must hope that such events are infrequent and involve only the most crucial questions of the day (indeed, questions that squarely implicate our most fundamental legal and moral values).

In sum, then, Professor Seidman has done a masterful job of mapping out the legal, moral, and political implications of resigning - or not resigning from public office over a policy disagreement with the president. With that said, however, public law scholarship should probably give greater attention to the option of "just saying no." Plainly, greater scholarly attention and scrutiny on the legal, moral, and political implications of intentional acts of insubordination would be both useful and necessary in order to evaluate fully and conclusively the practice's potential costs and benefits. Defining precisely when law, morality, and politics would support holding one's ground and forcing the president to choose between firing an appointee or accepting an act of insubordination lies beyond the scope of this essay; the phenomenon merits consideration as a plausible "third way" for a highlevel presidential appointee faced with a presidential order that she is not prepared to implement. ${ }^{84}$

${ }^{84}$ It bears noting that my discussion of "just saying no" should be, indeed must be, limited to the very highest political appointees within the executive branch of the federal government. Obviously, low-level employees of the Social Security Administration or the Merit Systems Protection Board must not be free to "just say no" if federal agencies are to honor basic Fifth Amendment due process rights implicating fair and equal treatment. See Hecklerv. Campbell, 46 I.S. 458 (1983). One aspect of fundamental faimess is that like cases be decided in the same way. Accordingly, only those with substantial responsibility for making agency-wide policy within a federal executive department or agency could justifiably elect to disregard a binding presidential directive in order to advance higher level values, such as fidelity to the Constitution or the rule of law. 